\title{
Microbial aggregation and degradation of phytoplankton-derived detritus in seawater. I. Microbial succession
}

\author{
Bopaiah A. Biddanda*, Lawrence R. Pomeroy \\ Institute of Ecology, University of Georgia, Athens, Georgia 30602, USA
}

\begin{abstract}
We have examined the microbial processes associated with degrading detritus from 3 phytoplankters in natural seawater. We describe a remarkably similar and well-defined pattern of microbial succession involving heterotrophic bacteria and bacterivorous protozoa occurring in all 3 cases. It appears that detritus aggregation, degradation and disaggregation are continuous processes occurring in the water column. The similarity in microbial processing of all detritus may be the reason why most particulate matter in the sea appears similar. A 'detritosphere' concept is proposed, under which the detritus-microbe environment may be considered in its natural context. We see the fate of detritus in the water column as aggregation-disaggregation sequences in time and space
\end{abstract}

\section{INTRODUCTION}

In a general sense, most particulate matter in the sea originates from phytoplankton production, and it is becoming evident that marine microheterotrophic activity may be closely associated with that of the primary producers not only in the utilization of dissolved organic matter from living phytoplankton, but also in utilization of dead phytoplankton (ZoBell 1946, Sieburth 1968, Douglas 1985). Several workers have reported that bacterial numbers (Wood 1963, ZoBell 1963, Hoppe 1981), as well as microheterotrophic activity (Droop \& Elson 1966, Sieburth 1968, Vaccaro et al. 1968, Bell \& Mitchell 1972, Hoppe 1981) are enhanced in the vicinity of phytoplankton blooms. ZoBell \& Allen (1935) showed conclusively for the first time that bacteria and, to a lesser extent, other microorganisms are the primary film formers on submerged surfaces; the succession of bacteria, heterotrophic flagellates and ciliates following phytoplankton blooms at sea was first observed and described by Sorokin (1977).

Results of recent studies on microbial colonization of detritus from a variety of sources including seagrass

\footnotetext{
- Present address: Alfred Wegener Institute for Polar and Marine Research, D-2850 Bremerhaven, Federal Republic of Germany
}

(Fenchel 1970, Robertson et al. 1982), macroalgae (Linley \& Newell 1981, Biddanda 1985), phytoplankton (Hoppe 1981, Linley \& Newell 1984, Fukami et al. 1985b), zooplankton (Fukami et al. 1985b), animal feces (Pomeroy \& Diebel 1980, Jacobsen \& Azam 1984) and abandoned larvacean houses (Davoll \& Silver 1986), all point to an initial rapid growth by bacteria followed by growth of a community of protozoa. Newell (1984) and Linley \& Newell (1984) summarized the results of microcosm experiments on the degradation of detritus derived from several sources and emphasized the underlying common features, namely, the development of bacteria followed by appearance of microflagellates that control the bacteria numbers. Further, the results of Fukami et al. (1985a, b) suggest that during the process of decomposition of detritus derived from phytoplankton and zooplankton, the bacterial community involved undergoes a similar, but successive change in both generic composition and heterotrophic activity. They did not, however, address the role of protozoa during this microbial succession.

Biddanda (1985) observed that during the early phase of decomposition of particulate detritus (the 1 to $8 \mathrm{~d}$ period when bacterial numbers increased rapidly colonizing the detritus), aggregation and formation of macroaggregates occurred (detritus-microbe complexes), identical to those described by Hobbie et al. 


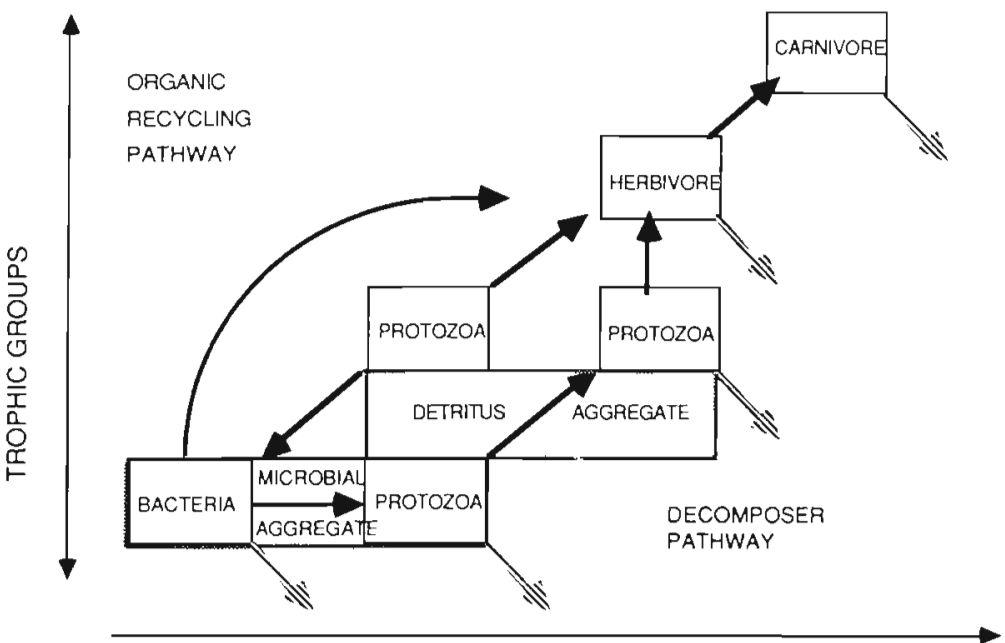

INCREASING SIZE
Fig. 1. Schematic model of the marine food web showing the 'aggregation effect' (modified from Williams 1981). It also indicates that aggregates of microorganisms, and aggregates of microorganisms and particulate detritus, experience a different trophic relationship as compared to the non-aggregated forms
(1972), Wiebe \& Pomeroy (1972), Pomeroy \& Diebel (1980), Linley \& Field (1981), Robertson et al. (1982), and Linley \& Newell (1984). But none of the studies so far describe the actual process of dissolution and disaggregation that occurs towards the later phase of detritus decomposition ( 8 to $16 \mathrm{~d}$ ). Both of these events are of considerable significance to the functioning of marine food chains (Fig. 1). The early aggregates represent a food resource for metazoan consumers capable of exploiting them (Biddanda 1985), whereas it would appear that aggregates escaping such a fate would undergo further dissolution due to gradual microbial activity and would be of little food value to metazoans. On the other hand, this implies that different nutrient regeneration rates occur in the above 2 scenarios.

From these considerations, it would appear that the ability of microbes to adhere or stay close to the detritus is important in determining the fate of detritus in the sea (Azam \& Ammerman 1984, Biddanda 1986). It is, therefore, necessary to understand the succession of microbes associated with the decomposition of detritus in conjunction with a simultaneous description of the status of the detritus-microbe complex itself. But such a phenomenon has not yet been described.

During our earlier work with degrading detritus (Pomeroy \& Diebel 1980, Biddanda 1985), we observed that the process of microbial succession (involving growth of bacteria and protozoa) is closely linked to the status of the detritus itself (aggregation and disaggregation, respectively), during long-term (several days) experiments. We propose that although particulate detritus may be processed through several different pathways in the marine food chain, there appear to be some quite general processes of particle aggregation and degradation, and that is why most particles, regardless of their immediate origin, look much alike and have similar fates. In this study, we ask the question: What are the microbial processes involved in the aggregation and disaggregation of detritus? We describe time-course observations of the behavior of detritus from 3 different phytoplankters degrading in natural seawater.

\section{MATERIALS AND METHODS}

Axenic cultures of 3 phytoplankton from diverse taxonomic groups were grown under clean-room conditions. These consisted of Synechococcus sp. (photo-

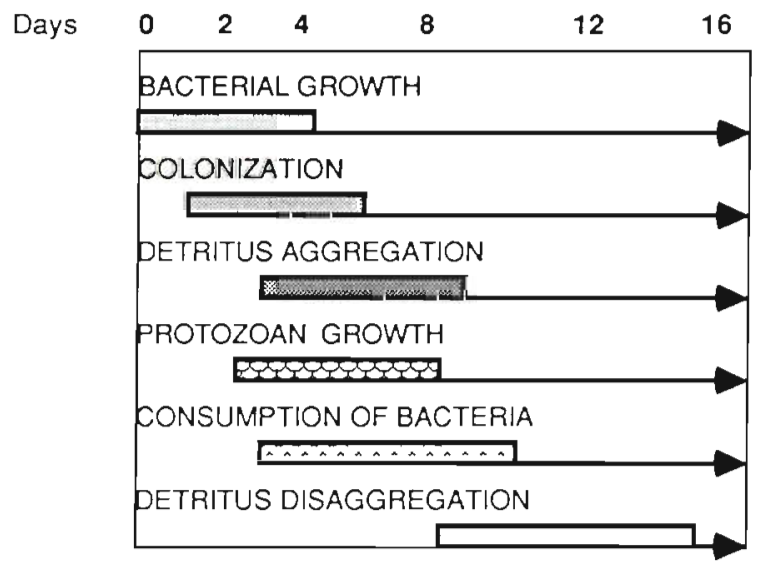

Fig. 2. Schematic diagram of microbial succession during phytoplankton decomposition in seawater 

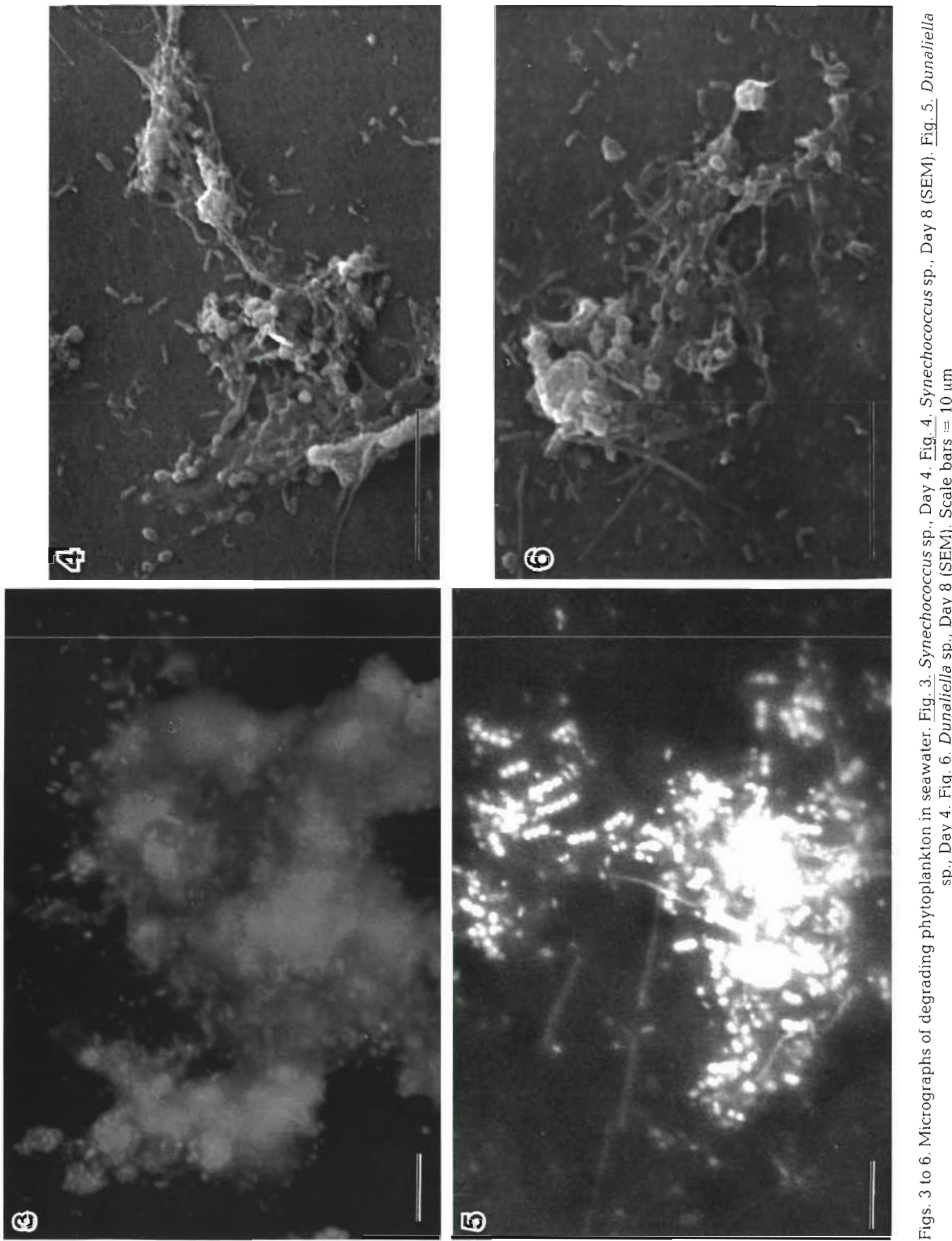

$8 \infty$

용

$\stackrel{0}{2}$

को के

अं।

고옹

प

\%

茎 0

的诖

$\Xi \dot{\nabla}$

동

:

萡

응

点

只

宁

G

$\stackrel{0}{0}$

里

전

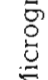

$\sum$

๑

$\vec{m}$

它 

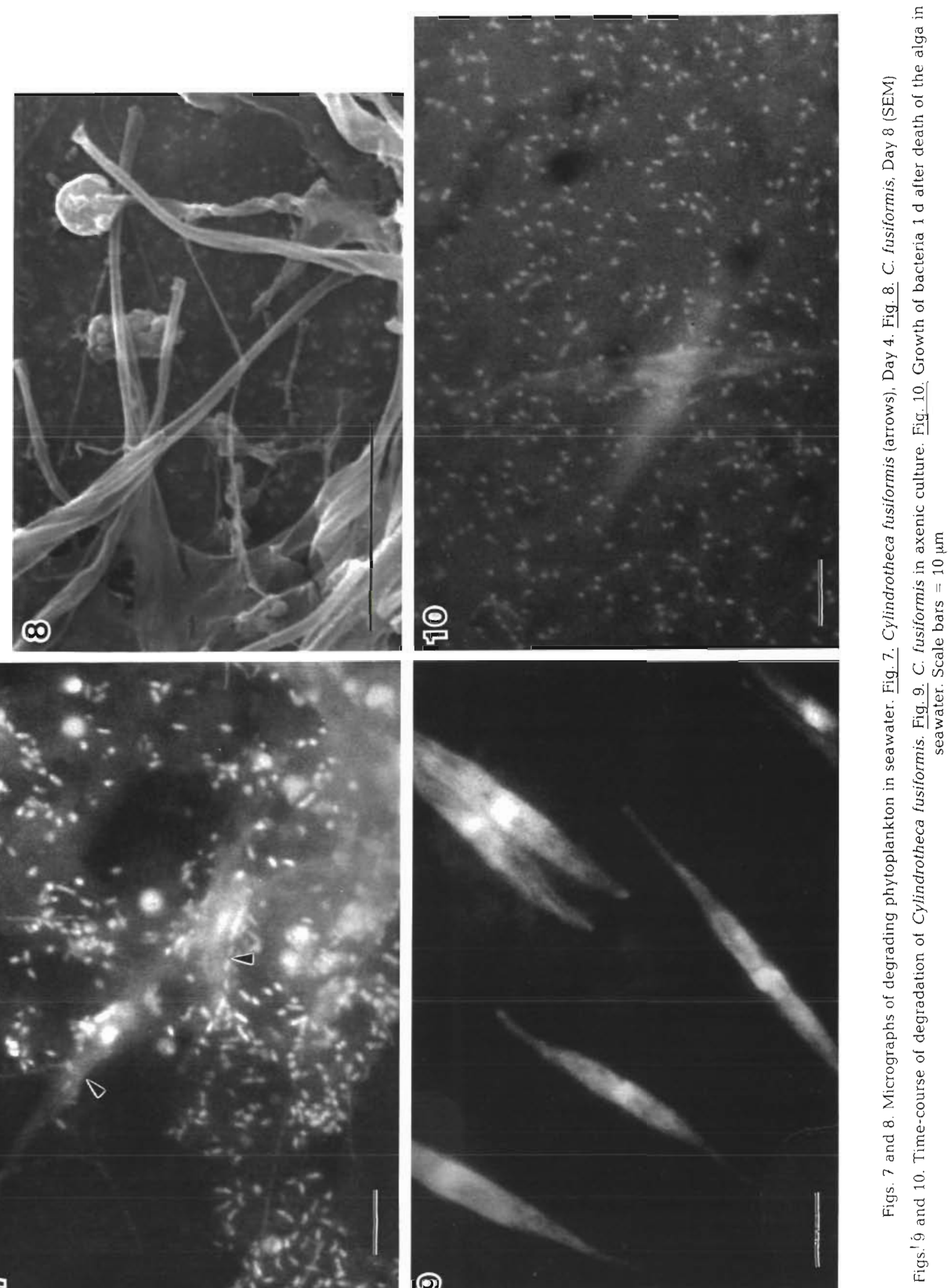

$\mathbb{N}$
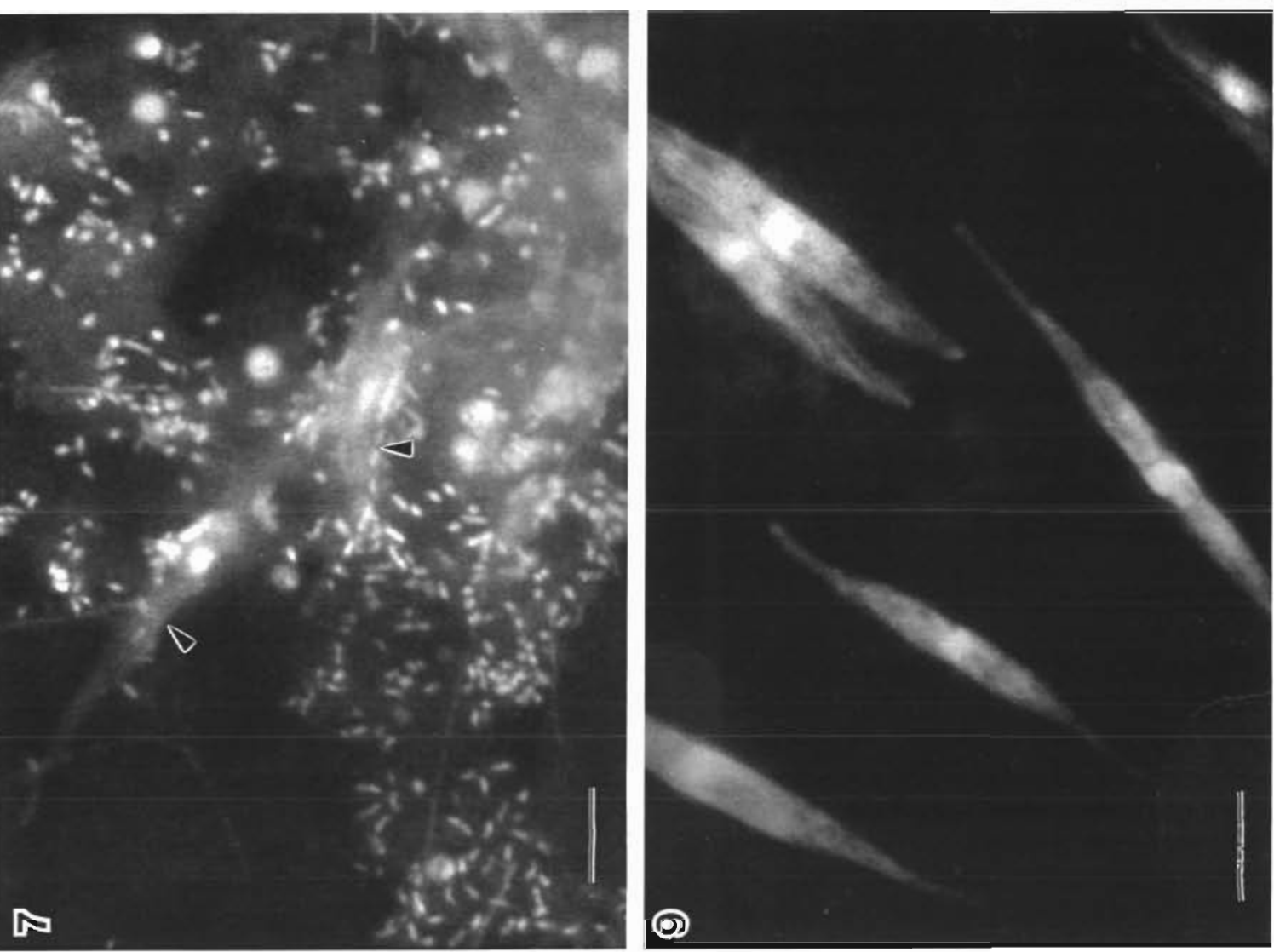

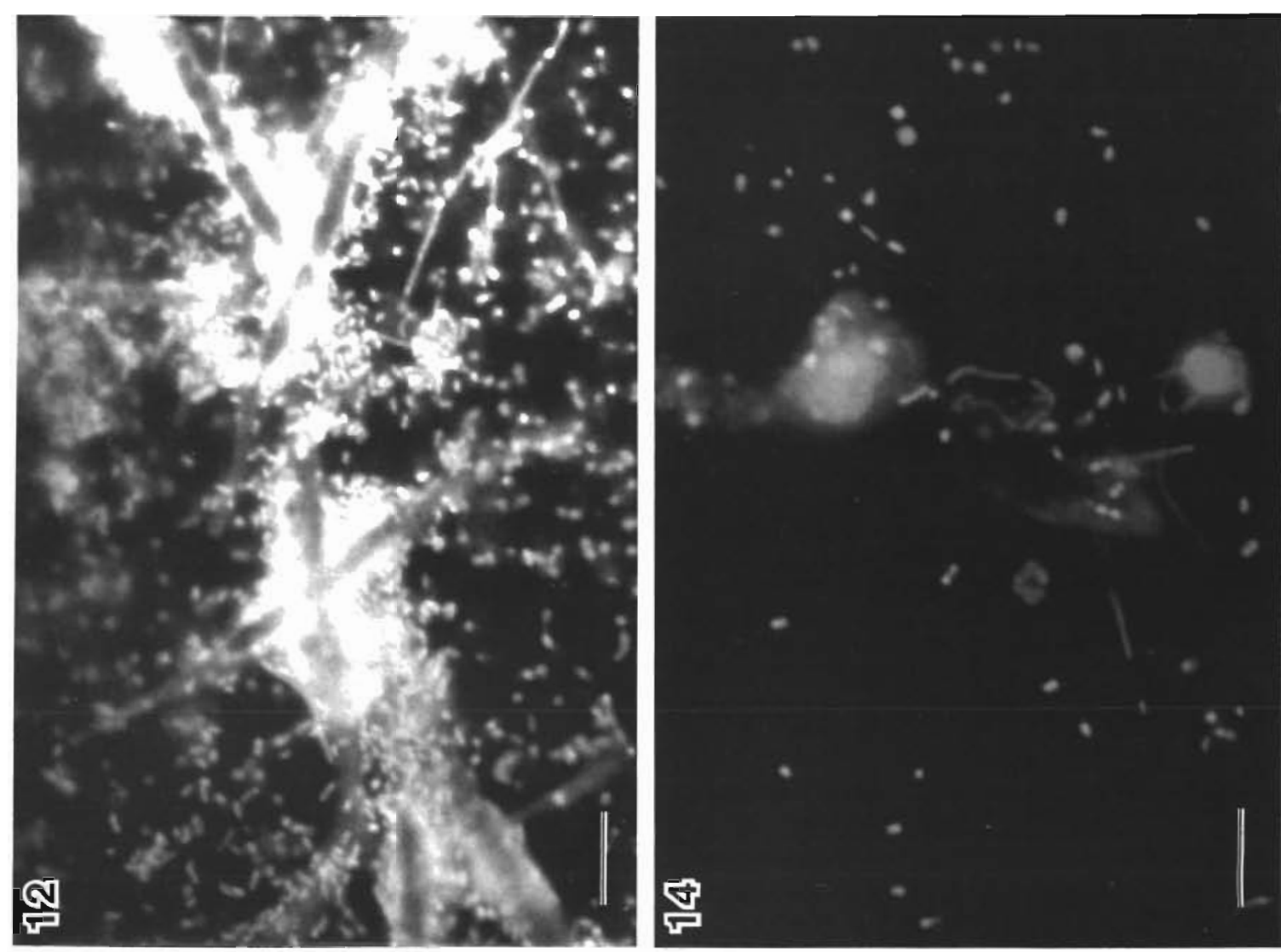

ते

ती

语过

웡

菏

司票焉

常

要的

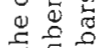

要需

동

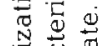

政

용

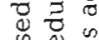

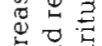

要通

范

里

过

5 .

교요

可记

两

$-13$
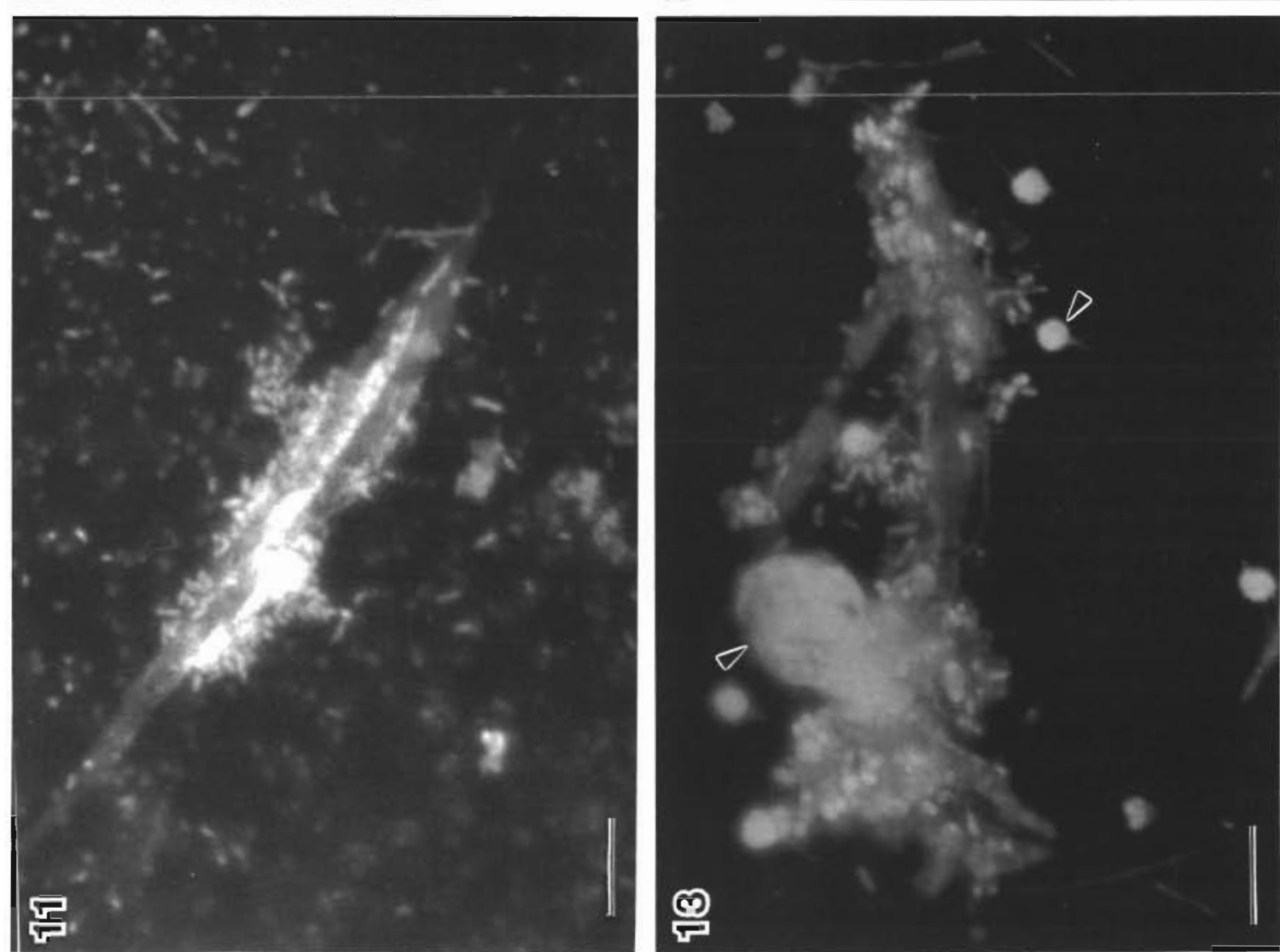

我新

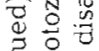

$\Xi \Xi$

क

远

告

ह

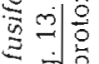

o 0 이응

प्र

용

원

궁

응

द है

范

중

总客

잉

$\square$.

릉

今०

i

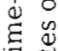

晋焉

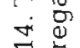

음

․

s: 

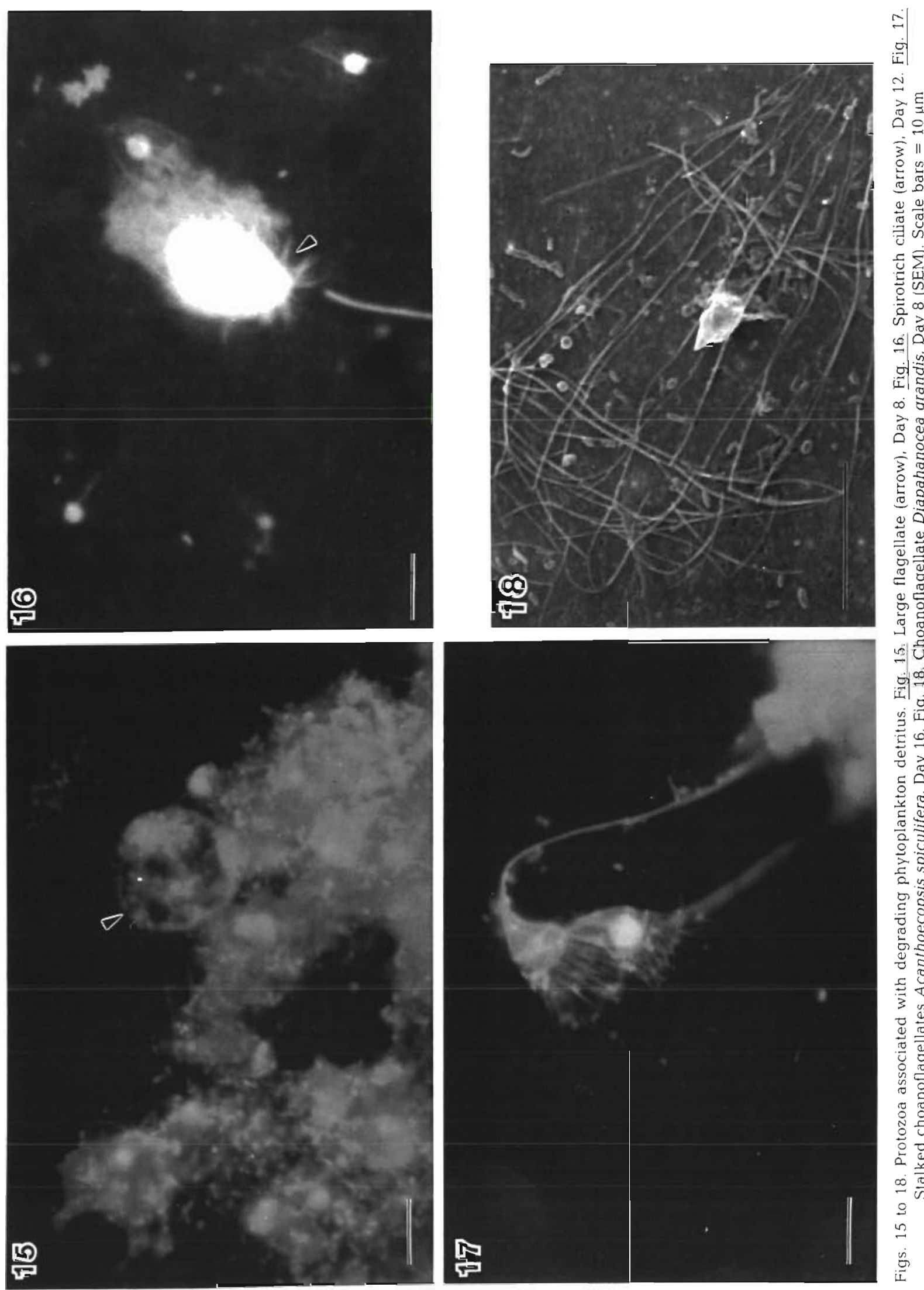
autotrophic cyanobacteria), Dunaliella sp. (autotrophic flagellate), and Cylindrotheca fusiformis (pennate diatom). At the end of the exponential phase of growth (approximately $14 \mathrm{~d}$ ), the cultures were freeze-thaw killed $\left(-40\right.$ and $55^{\circ} \mathrm{C}$ ) and made up in unfiltered natural seawater (mid-shelf surface water off Georgia, USA) to bring the total carbon concentration to approximately $10 \mathrm{mg} \mathrm{l}^{-1}$. We used concentrations of organic matter comparable with those found under natural conditions, such as phytoplankton blooms at sea (Newell et al. 1981, Fukami et al. 1985a, b), and avoided using extremely high and unrealistic levels used by some earlier workers (Otsuki \& Hanya 1972, Miyoshi 1976). Aliquats of $1 \mathrm{ml}$ of this phytoplankton detritus were suspended in $10 \mathrm{ml}$ of unfiltered seawater and transferred into clean acid-washed $20 \mathrm{ml}$ glass scintillation vials with conical polyethylene caps. These were incubated in the dark at $26^{\circ} \mathrm{C}$ and gently shaken on a reciprocal shaker.

At various time intervals (between 0 and $16 \mathrm{~d}$ ) duplicate microcosms (vials) were preserved in acidified Lugol's solution. Subsamples from these were filtered onto 0.22 um pore-size Nuclepore filters and stained with acridine orange and the events followed by epifluorescence microscopy (Nishino 1986), so that numbers of microorganisms and their relation to particles could be described. For scanning electron microscopy (SEM), the samples were prepared in a clean room, filtered onto $0.22 \mu \mathrm{m}$ pore-size Nuclepore filters and examined using a Philips Model 505 scanning electron microscope.

\section{RESULTS}

Time-course microscopic observations of detritus from the 3 phytoplankters showed that they all go through a similar progression of events (Fig. 2), namely: growth of bacteria, colonization of bacteria on detritus, aggregation of detritus, growth of protozoa, consumption of bacteria, and disaggregation of detritus aggregates. The highlights in Fig. 2 indicate the temporal range in which that particular process is most frequent; after Day 4, most of the processes are occurring concurrently.

While preliminary observations indicated that microbiological events were similar in all the 3 phytoplankton undergoing decomposition, Synechococcus sp. (at Day 4, Fig. 3; Day 8, Fig. 4) and Dunaliella sp. (at Day 4, Fig. 5; Day 8, Fig. 6) become impossible to identify by microscopy by Day 4 (as with most detritus at sea), but Cylindrotheca fusiformis (at Day 4, Fig. 7; Day 8, Fig. 8) was easily identified because of the conspicuous shape of its siliceous frustules persisting within the aggregate (arrows). Hence we have chosen to illustrate the different stages, identified in Fig. 2, through a time-course sequence of degrading $C$. fusiformis because it presents a more continuous visual argument.

Day O. Axenic culture of live Cylindrotheca fusiformis (Fig. 9).

Day 1. A day after death and addition of seawater. Growth of bacteria, primarily free, individual cells in the water (Fig. 10).
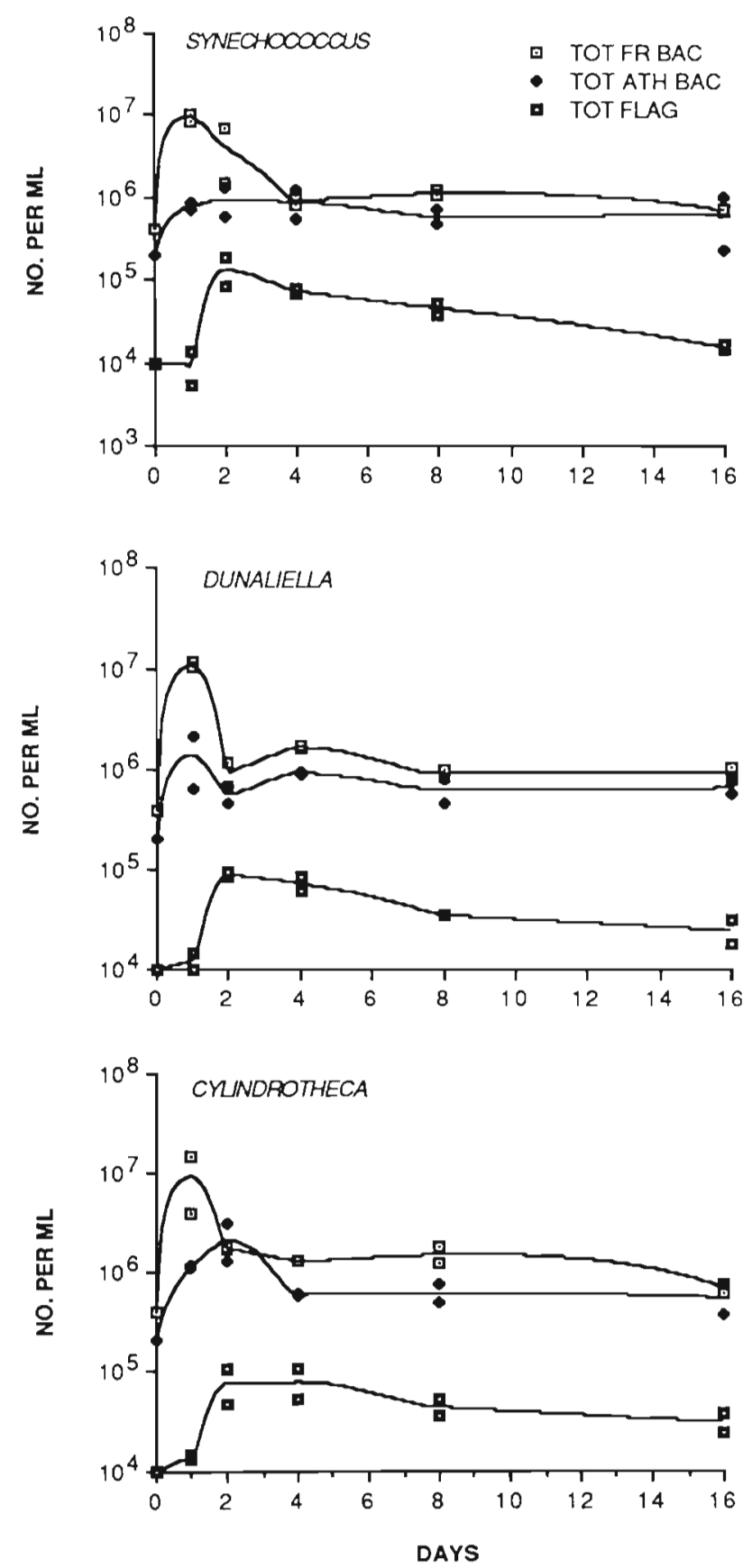

Fig. 19. Changes in the microbial community associated with decomposition of Synechococcus sp., Dunaliella sp. and Cylindrotheca fusiformis in seawater TOT FR BAC: total free bacteria; TOT ATH BAC: total attached bacteria; TOT FLAG: total flagellates 
Day 2. Colonization of the phytoplankton detritus by bacteria (Fig. 11).

Day 4. Aggregation of bacteria and detritus. Protozoa generally became abundant at this time (Fig. 12).

Day 8. Many bacteria have been consumed by protozoa (Fig. 13).

Day 16. Most of the detritus is utilized. Aggregates have broken up and largely disappeared (Fig. 14).

Figs. 15 to 18 illustrate some of the many different protozoan forms that appeared between Days 8 and 16 in all the 3 degrading phytoplankton.

This similarity was also reflected in the microbial composition of the 3 phytoplankters during their decomposition (Fig. 19). Following the addition of detritus to seawater, there was in all the cases an identical response in terms of increase in free and attached bacteria, followed by the increase in flagellate numbers. Subsequently, there was a decrease in bacteria numbers, indicating that protozod control the numbers of bacteria

\section{DISCUSSION}

\section{Colonization and aggregation}

Davoll \& Silver (1986) suggested that marine aggregates are microhabitats in the pelagic zone, possessing some combined features of both pelagic and benthic systems, since they provide surfaces for microbial colonization in the pelagic environment

During the first few days of incubation of detrital material in seawater there appears an increasing proportion of rod-shaped bacteria. These are then replaced by a mixed assemblage of bacteria that are cocci, spirilla, rods, and filamentous forms (Linley \& Newell 1984, Biddanda 1985). It has been further shown that aggregate formation is microbially mediated through the production of sticky extracellular mucopolysaccharides by bacteria (Biddanda 1986). Subsequently, a mixed assemblage of bacterivorous protozoa such as flagellates, ciliates, choanoflagellates, and amoeboids forms arise that keep bacterial numbers in check. Similar observations have been made for detritus derived from a variety of sources by Fenchel \& Harrison (1976), Pomeroy \& Diebel (1980), Linley \& Newell (1984) and Biddanda (1985). These studies describe the microbial food chain dependent on detritus as a succession of events.

\section{Consumption and disaggregation}

Subsequent to the appearance of the protozoan community and reduction of bacteria, the next characteris- tic change in aggregate morphology occurs. While the aggregate may remain relatively stable as long as the aggregates maintain their integrity, and successional events may occur repeatedly on such particles (Fenchel 1970), most often they undergo disaggregation due to the combined activity of bacteria and protozoa. Bacteria rapidly convert the POC (particulate organic carbon) in the detritus into DOC (dissolved organic carbon) by means of exoenzymes and assimilate as well as respire it (Hoppe 1984). Protozoa, on the other hand, consume the bacteria and associated attachment structures and disrupt the integrity of the aggregates by their burrowing activities. Pomeroy \& Diebel (1980), working with degrading salp feces, were the first to recognize such a process of aggregate dissolution and the role of protozoa in it. Protozoa seem to contribute to the breakup of aggregates in a manner analogous to the effect of smaller invertebrates on the degradation of forest litter. More recently, similar events have been noted by Beeftink \& Staugaard (1986) in their study of anaerobic bacterial aggregates in waste-water treatment plants.

As mentioned earlier (Fig. 1), both these events of aggregation and disaggregation of detritus are of significance to the functioning of marine food chains. While the microbe-rich aggregated phase may be of food value to the metazoans (Biddanda 1985), the events following (the microbe-poor disaggregated state) may be of nutrient value to the primary producers in the community. For example, previous microcosm studies with terrestrial assemblages (Coleman et al 1978, Elliot et al. 1979) and marine assemblages (Johannes 1965, Fenchel \& Harrison 1976, Fenchel 1977) have demonstrated that phagotrophic protozoans accelerate decomposition and enhance the rates of inorganic nutrient regeneration. This idea is further supported by recent work by Taylor and coworkers $(1985,1986)$, showing that the presence of bacterivorous zooflagellates stimulates bacterial metabolism and. growth activity resulting in the rapid recycling of nutrients within the microbial assemblage associated with particles in the sea.

\section{The 'detritosphere effect'}

The rapid turnover of microbial populations and of mineral nutrients in oligotrophic waters has inspired several authors to consider whether the microbial populations predominantly occur in some sort of a structured nutrient environment (Azam \& Ammerman 1984) or macroaggregates (Goldman 1984). Bacterial and microzooplankton activity may even establish a microzone of enriched nutrients in and around the aggregate (Hoppe 1981), and microorganisms may 
optimize their position within such nutrient fields leading to the formation of 'microbial clusters' in the vicinity of such detritus aggregates (Azam \& Ammerman 1984). We propose to call this microenvironment of the degrading detritus, the 'detritosphere', similar to the phycosphere concept advanced by Bell \& Mitchell (1972) to describe the environment of bacteria associated with live phytoplankton exuding soluble organic materials. The detritosphere concept offers a context in which to consider the important functions of past primary production, current heterotrophic bacterial growth and bacterivory as closely associated in space and time in the case of degrading detritus aggregates in the sea. In the sea, microheterotrophic population fluctuations are triggered by phytoplankton blooms which lead to increased bacterial growth, followed by protozoa (Fenchel 1987). The basic observation in this study has been that regardless of its source, organic detritus suspended in seawater develops a remarkably similar and well-defined sequence of microbial succession. The rapid response of the microbial community to inputs of organic detritus, and the close spatial association that they share with the particulate environment, indicate a detritosphere effect.

\section{Model of aggregate dynamics}

It has been shown earlier that in both natural samples of seawater and culture experiments, there is a regular process of aggregation of organic matter associated with bacterial utilization of particulate substrates (Biddanda 1985), and that particle aggregation is mediated by bacterial extracellular products which cause bacteria to adhere to solid surfaces or particles (Biddanda 1986). Further, in this study we have observed that as time progresses, the combined activities of bacteria utilizing the substrates and protozoa consuming the bacteria result in aggregate disaggregation. The aggregates grow in seawater, often forming visible 'sea snow' that settles gradually to the deeper layers. At the same time, particles are also being converted to dissolved materials by the enzymes of bacteria, possibly the same bacteria that are aggregating the particles. The protozoa further accelerate this process by grazing on bacteria and disrupting the aggregates by their burrowing activity. Therefore, we see a continuing process of particle formation, growth, sinking and dissolution. A sample from coastal water therefore contains all stages in this process.

We propose an emerging hypothesis for the behavior or life history of detritus in the water column (Fig. 20). The model is driven by the inputs from primary and secondary producers. The model is also more or less

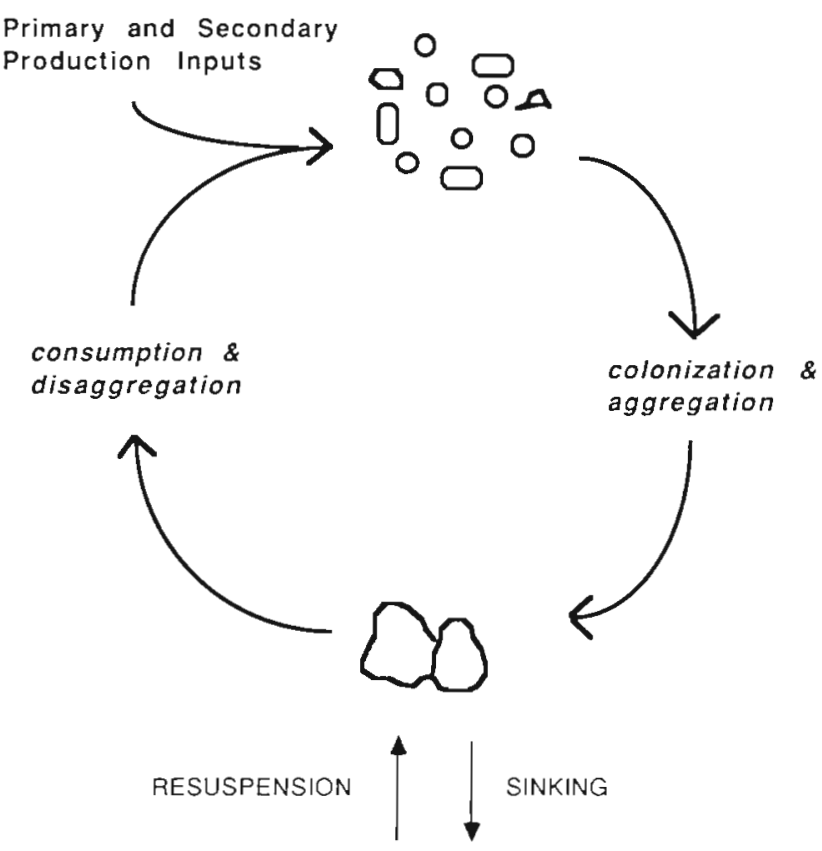

Fig. 20. Schematic model of detritus behavior in the water column, showing cycle of aggregation-disaggregation of detritus

internally consistent since loss of detritus and biomass by respiration and sinking are compensated through new primary and secondary production inputs as well as resuspension from the deeper layers and the benthos. It is known that large aggregates (sea snow) are associated with productive situations. We suggest that, regardless of the form of organic input (mucus, feces, appendicularian houses, dead animals, or dying phytoplankton), particulate matter is aggregated by bacteria and subsequently degraded by them, together with the actions of protozoa, eating bacteria and physically breaking up the particles. Therefore, in a general sense, we see the fate of detritus in the water column as aggregation-disaggregation sequences in time and space.

Acknowledgements. This research was supported through a U.S. Department of Energy contract (DE-FG09-86ER60451) to LRP. Robert Hodson, William Wiebe and Karen Porter read and improved the first draft of the manuscript. Shane Kjeldahl assisted in the preparation of scanning electron micrographs. Les Carlough helped with the identification of protozoa. Patty Freeman-Lynde helped with the preparation of the figures. Comments by 3 anonymous reviewers helped improve this article considerably. We are grateful for all this support. comments, and help.

\section{LITERATURE CITED}

Azam, F., Ammerman, J. W (1984). Cycling of organic matter by bacterioplankton in pelagic marine systems: micro- 
environmental considerations. In: Fasham, M. J. R. (ed.) Flows of energy and materials in marine ecosystems. Plenum Press, New York, p. 345-360

Beeftink, H. H., Staugaard, P. (1986). Structure and dynamics of anaerobic bacterial aggregates in a gas-lift reactor Appl. environ. Microbiol. 52 (5): 1139-1146

Bell, W., Mitchell, R. (1972). Chemotactic and growth responses to marine bacteria to algal extracellular products. Biol. Bull. mar. biol. Lab., Woods Hole 143: 265-277

Biddanda, B. A. (1985). Microbial synthesis of macroparticulate matter. Mar. Ecol. Prog. Ser. 20: 241-251

Biddanda, B. A. (1986). Structure and function of marine microbial aggregates. Oceanol. Acta 9(2): 209-211

Coleman, D. C., Anderson, R. V., Cole, C. V., Elliot, E. T., Wood, L., Campion, M. K. (1978). Trophic interactions in soils as they affect energy and nutrient dynamics. 4. Flows of metabolic and biomass carbon. Microb. Ecol. 4: 373-380

Davoll, P. J., Silver, M. W. (1986). Marine snow aggregates: life history sequence and microbial community of abandoned larvacean houses from Monteray Bay, California. Mar. Ecol. Prog. Ser. 33: 111-120

Douglas, D. J. (1985). Spatial association and trophic coupling of heterotrophic bacteria with phytoplankton. Ph.D. thesis, Dalhousie University, Canada

Droop, M. R., Elson, K. G. R. (1966). Are pelagic diatoms free from bacteria? Nature, Lond. 211: 1096-1097

Elliot, E. T., Cole, C. V., Coleman, D. C., Anderson, R. V., Hunt, H. W., McClellan, J. F. (1979). Amoebal growth in soil microorganisms: a model system of carbon, nitrogen and phosphorus. Trophic dynamics. Int. J. environ. Stud. 13: 169-174

Fenchel $T$ (1970). Studies on the decomposition of organic detritus derived from the turtle grass, Thalassia testudinum. Limnol. Oceanogr. 15: 14-20

Fenchel, T. (1977). The significance of bacterivorous protozoa in the microbial community of detrital particles. In: Cairns, J. (ed.) Aquatic microbial communities. Garland Publ., New York, p. 529-545

Fenchel, I (1987). Ecology of protozoa: the biology of freeliving phagotrophic protists. Brock/Springer Ser. Contemporary Bioscience. Springer-Verlag, New York, p. 86-151

Fenchel, T., Harrison, P. (1976). The significance of bacterial grazing and mineral cycling for the decomposition of particulate detritus. In: Anderson, J. M., MacFadyen, A. (eds.) The role of terrestrial and aquatic organisms in decomposjtion processes. Blackwell, Oxford, p. 285-299

Fukami, K., Simidu, U., Taga, N. (1985a). Microbial decomposition of phyto- and zooplankton in sea water. 1. Changes in organic matter. Mar. Ecol. Prog. Ser 21 1-5

Fukami, K., Simidu, U., Taga, N. (1985b). Microbial decomposition of phyto- and zooplankton in sea water. 2. Changes in the bacterial community. Mar. Ecol. Prog. Ser. 21: 7-13

Goldman, J. C. (1984). Oceanic nutrient cycles. In: Fasham, M. J.R. (ed.) Flows of energy and materials in marine ecosystems. Plenum Press, New York, p. 137-170

Hobbie, J. E., Holm-Hansen, O., Packard, T T., Pomeroy, L. R., Sheldon, R. W., Thomas, J. P., Wiebe, W. J. (1972) A study of the distribution of activity of microorganisms in ocean water. Limnol. Oceanogr. 17: 544-555

Hoppe, H.-G. (1981). Blue-green algae agglomeration in surface water a microbiotope of high bacterial activity. Kieler Meeresforsch. (Sonderh.) 5: 291-303

Hoppe, H.-G. (1984). Attachment of bacteria advantage or disadvantages for survival in the aquatic environment. In: Marshall, K. C. (ed.) Microbial adhesion and aggregation. Dahlem Konferenzen. Springer-Verlag, Berlin, p. 283-301
Jacobsen, T R., Azam, F. (1984). Role of bacteria in copepod fecal pellet decomposition: colonization, growth rates and mineralization. Bull. mar Sci. 35: 495-502

Johannes, R. E. (1965). Influence of marine protozoa on nutrient regeneration. Limnol. Oceanogr. 10: 434-442

Linley, E. A. S., Field, J. G. (1981). The nature and ecological significance of bacterial aggregation in west-coast kelp beds. Estuar. coast. Shelf Sci. 14: 1-11

Linley, E. A. S., Newell, R. C. (1984). Estimates of bacterial growth yields based on plant detritus. Bull. mar. Sci. 25 (3) $409-425$

Miyoshi, H. (1976). Decomposition of marine plankton under laboratory conditions. Bull. Jap. Soc. scient. Fish. 42 $1205-1211$

Newell, R. C. (1984). The biological role of detritus in the marine environment. In: Fasham, M. J. R. (ed.) Flows of energy and materials in marine ecosystems. Plenum Press New York, p. 317-343

Newell, R. C., Lucas, M. I., Linley, E. A. S. (1981). Rate of degradation and efficiency of conversion of phytoplankton debris by marine microorganisms. Mar. Ecol. Prog. Ser. 6 : 123-136

Nishino, S. (1986). Direct acridine orange counting of bacteria preserved with acidified Lugol's iodide. Appl. environ. Microbiol. 52: 602-604

Otsuki, A., Hanya, T. (1972). Production of dissolved organic matter from dead green algal cells. 1. Aerobic microbial decomposition. Limnol. Oceanogr. 17 (2): 248-257

Pomeroy, L. R., Diebel, D. (1980). Aggregation of organic matter by pelagic tunicates. Limnol. Oceanogr. 25 (4): 643-652

Robertson, M. L., Mills, A. L., Zieman, J. C. (1982). Microbial synthesis of detritus-like particulates from dissolved organic carbon released by tropical seagrass. Mar. Ecol Prog. Ser 7: 279-285

Sieburth, J. McN. (1968). The influence of algal antibiosis on the ecology of marine microorganisms. In: Droop, M. R (ed.) Advances in microbiology, Vol. 1. Academic Press, New York, p. 63-94

Sorokin, Yu. I. (1977). The heterotrophic phase of planktonic succession in the Japan Sea. Mar. Biol. 41: 107-117

Taylor, G. T., Itirriaga, R., Sullivan, C. W. (1985). Interactions of bacterivorous grazers and heterotrophic bacteria with dissolved organic matter. Mar. Ecol. Prog. Ser. 23: 129-141

Taylor, G. T., Karl, D. M., Pace, M. L. (1986). Impact of bacteria and zooflagellates on the composition of sinking particles: an in situ experiment. Mar. Ecol. Prog. Ser. 29: 141-155

Vaccaro, R. F., Hicks, S. E., Jannasch, H. W., Carey, F. G. (1968). The occurrence and role of glucose in sea water. Limnol. Oceanogr. 13: 356-360

Wiebe, W. J., Pomeroy, L. R. (1972). Microorganisms and their association with aggregates and detritus in the sea: a microscopic study. In: Melchiom-Santolini, U., Hopton, J. W. (eds.) Detritus and role in the aquatic ecosystem. Memone Ist. ital. Idrobiol. 24 (Suppl.): 325-352

Wood, E. J. F. (1963). Some relationships of phytoplankton to environment. In: Oppenheimer, C. H. (ed.) Marine microbiology. Thomas, Springfield, Illinois, p. 275-285

ZoBell, C. E. (1946). Marine microbiology. Chronica Botanica, Waltham, Massachusetts

ZoBell. C. E. (1963). Domain of the marine microbiologist. In: Oppenheimer, C. H. (ed.) Marine microbiology. Thomas, Springfield, Illinois, p. 3-24

ZoBell, C. E., Allen, E. C. (1935). The significance of marine bacteria in the fouling of submerged surfaces. J. Bacteriol. 29-30 (3): 239-252 